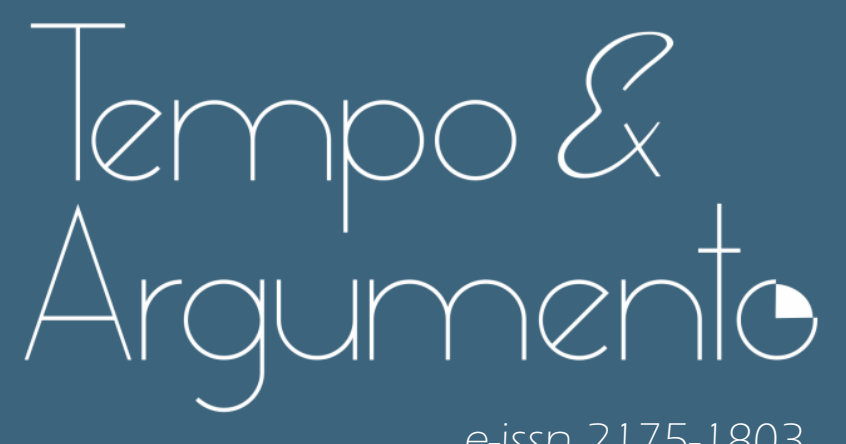

e-issn 2175-1803

\title{
Delatores e práticas de delação no limiar da Ditadura Militar do Brasil
}

\section{- Angelo Priori}

Doutor em História e Sociedade pela Universidade Estadual Paulista Júlio de Mesquita Filho (UNESP). Professor do Programa de Pós-Graduação em História da Universidade Estadual de Maringá (UEM).

Maringá, PR - BRASIL

lattes.cnpq.br/9430424742681196

angelopriori@uem.br

(D) orcid.org/0000-0002-9155-5428

- Leandro Brunelo

Doutor em História pela Universidade Estadual de Maringá (UEM).

Professor da Universidade Estadual de Maringá (UEM).

Maringá, PR - BRASIL

lattes.cnpq.br/ 1444034355199758

Ibrunelo@uem.br

(D) orcid.org/0000-0001-5613-4591

Para citar este artigo:

PRIORI, Angelo; BRUNELO, Leandro. Delatores e práticas de delação no limiar da Ditadura Militar do Brasil. Tempo e Argumento, Florianópolis, v. 13, n. 32, e0201, jan./abr. 2021.

doi http://dx.doi.org/10.5965/2175180313322021 e0201

Recebido: 23/05/2020

Aprovado: 08/02/2021 


\title{
Delatores e práticas de delação no limiar da Ditadura Militar do Brasil
}

\begin{abstract}
Resumo
O objetivo deste trabalho é analisar a atuação dos delatores voluntários e dos informantes colaboracionistas durante a Ditadura Militar no Brasil (1964-1985). Para isso, utilizamos as cartas e os bilhetes enviadas por cidadãos comuns aos órgãos de segurança e para a polícia política, delatando militantes políticos, vizinhos, colegas de trabalho e amigos. A documentação analisada encontra-se no Fundo DOPS, arquivada no Departamento Estadual de Arquivo Público do Paraná (DEAP). Constatamos que a prática da delação era bastante comum durante a Ditadura Militar e que os delatores tiveram papel importante, contribuindo com os órgãos de segurança do regime militar, no processo de vigilância e de controle social da população brasileira.
\end{abstract}

Palavras-chave: Ditadura Militar. Polícia Política. Delação. Cidadãos Comuns.

\section{Whistleblowers and whistleblowing practices during the Brazilian Military Dictatorship}

\begin{abstract}
The activities of voluntary whistleblowers and collaborating informants during the Military Dictatorship in Brazil (1964-1985) are investigated. Letters and memos sent by several common people to security departments and political police informing on political adversaries, neighbors, co-workers and friends are analyzed. The documents under investigation have been retrieved from the DOPS archives at the State Department of the Public Archives of the State of Paraná (DEAP). Whistleblowing was a very common practice during the Military Regime and informants had an important role conniving with the regime 's security organs within the vigilance and social control process of the Brazilian population.
\end{abstract}

Keywords: Military Dictatorship. Political Police. Whistleblowing. Common Citizens. 


\section{Introdução}

No filme “O que é isso companheiro?", de Bruno Barreto (1997), inspirado no livro homônimo de Fernando Gabeira (2009), existem duas cenas que passam quase desapercebidas pelos espectadores preocupados com o enredo cinematográfico. Para relembrar, o filme (uma mescla de ficção e realidade) foi lançado nos EUA, com o título de Four days in september, e narra o sequestro do embaixador americano Charles Burke Elbrick, ocorrido no mês de setembro de 1969, na cidade do Rio de Janeiro, organizado pelo Movimento Revolucionário 8 de Outubro (MR-8) e pela Aliança Libertadora Nacional (ALN), duas organizações da resistência armada contra a Ditadura Militar no Brasil. O filme foi sucesso de bilheteria e chegou a concorrer ao Oscar de melhor filme estrangeiro naquele ano. No Brasil, o filme ganhou grande repercussão, proporcionando acalorado debate tanto entre a crítica especializada quanto entre a intelectualidade e a esquerda, sobretudo a que tinha sobrevivido à forte repressão da ditadura. ${ }^{1}$

A primeira cena a que nos referimos é estrelada pela personagem da atriz Fernanda Montenegro - "Margarida" (a partir do minuto 30:14"). Da janela de seu apartamento, a personagem observa a movimentação na rua Marques esquina com a rua Capistrano de Abreu, bairro de Botafogo, cidade do Rio de Janeiro, local onde os militantes do MR-8 e da ALN prepararam a emboscada para a captura do embaixador. Desconfiada, Margarida telefona aos órgãos de segurança e informa ao interlocutor: "meu senhor, há três homens e uma mulher em um carro, aqui na esquina da rua Capistrano de Abreu com a rua Marques, em atitude suspeita". Perguntada o que ela entendia como "atitude suspeita", Margarida responde: "estão lá a quase meia hora, parece que estão esperando alguém e estão muito nervosos". Naquele momento, a polícia não deu créditos à informação. Consumado o sequestro, coube à cismada Margarida murmurar: "eu sabia!".

A outra cena ocorre logo depois (a partir do minuto 53:16”). Júlio (Caio Junqueira), militante do MR-8, é encarregado pela direção de buscar comida para

\footnotetext{
Não vem ao caso e não é objetivo deste artigo delinear as críticas suscitadas tanto ao livro quanto ao filme. Para isso, remetemos à coletânea organizada e publicada pela Fundação Perseu Abramo, logo após o lançamento do filme (REIS FILHO et. al., 1997).
} 
os militantes e para o embaixador. Em uma padaria, encomenda oito galetos. Questionado pelo dono do comércio se ele tinha dinheiro para comprar "tudo isso", Júlio, mostrando um maço de dinheiro, responde ironicamente: "senhor eu tenho dinheiro para comprar 18, 20, 50 se eu quiser, mas eu só quero oito". Quando Júlio deixa o estabelecimento comercial, o padeiro de Santa Teresa (personagem do ator Antônio Pedro) liga para a polícia, informando do ocorrido. Dessa vez, os órgãos de segurança mandam investigar o caso.

Os exemplos acima de Margarida e do padeiro de Santa Teresa ilustram a ação e a prática de alguns sujeitos que tiveram participação, às vezes importante, às vezes nem tanto, em regimes autoritários e ditatoriais, entre eles a ditadura militar no Brasil. Trata-se dos delatores e dos colaboradores, muitas vezes, espontâneos, como parecem ser os casos de Margarida e do padeiro.

Para este estudo, buscamos exemplificar alguns casos que podem ser úteis para a compreensão e a análise do papel dos informantes e dos delatores, que trabalhavam como linha auxiliar dos órgãos de segurança no Brasil. No caso do Brasil, encontramos muitas informações, dispersas, é verdade, sobre delações, na documentação arquivada pelos órgãos de segurança.

Como não é possível, no espaço de um artigo, perscrutar toda essa documentação, nos limitaremos aos bilhetes e as cartas recolhidos pela Delegacia de Ordem Política e Social (DOPS)² do Estado do Paraná, nos primeiros anos da ditadura militar (1964-1985). Vale destacar, que a prática de delação acompanha a história do DOPS no Paraná (PRIORI, 2016; SILVA, R., 2017). Em momentos históricos em que a situação política está mais conturbada, essas práticas aumentavam significativamente. Pudemos verificar isso em alguns momentos importantes, como durante o período do Estado Novo (MONTEIRO, 2007; PEREIRA, 2017), sobretudo nos anos em que o Brasil se envolveu na Segunda Guerra Mundial, já que o Paraná é um Estado que recebeu ampla imigração dos países do Eixo: Alemanha, Itália e Japão; nos anos que antecederam ao golpe militar, durante o governo João Goulart e a atuação dos

\footnotetext{
2 DOPS é uma sigla usual para identificar a polícia política nos estados. Em alguns estados chamava-se Departamento de Ordem Política e Social (logo, utiliza-se o DOPS), em outros, Delegacia de Ordem Política e Social (logo, a DOPS). No Paraná era Delegacia. Porém, para efeito deste artigo, utilizaremos a sigla DOPS no masculino, já que é o mais usual na historiografia.
} 
chamados Grupos dos Onze (PRADELA, 2019; REGGIANI, 2015), bastante recorrente no Estado; e durante a ditadura militar (MAGALHÃES, 1997; 2009; SILVA, R.,2017).

Nos arquivos da Delegacia de Ordem Política e Social do Paraná (DOPS-PR) encontramos duas pastas sobre os informantes e os delatores. Uma chamada Informantes (DEAP, Fundo DOPS, pasta 797.94) e outra Informantes EOEIG Escola de Oficiais Especialistas e Infantaria de Guarda (DEAP, Fundo DOPS, pasta 798.94). A primeira é formada por relatórios de agentes policiais, recortes de jornais, cartas e bilhetes enviadas por diversas pessoas de diversas localidades do Paraná, num alcance temporal que vai dos anos 1930 aos anos 1980. Já a segunda, de menor dimensão documental, é composta por informes elaborados durante a década de 1970, por um único informante, que morava em um hotel, no bairro Batel, em Curitiba. Seus informes eram enviados, geralmente, para o comandante da Base Aérea do Bacacheri, denunciando pessoas que supostamente tinham vínculos com o Partido Comunista, mas também pessoas e lugares com algum vínculo com o tráfico de drogas. E há, dispersas em muitas pastas, bilhetes e cartas de pessoas que fizeram algum tipo de delação (como exemplo citamos as pastas 799.94, 1143a.137 e 1782.213). Através desse conjunto documental é possível verificar a atuação e a colaboração desses sujeitos anônimos, que voluntária ou involuntariamente, tiveram um papel importante no processo de vigilância e de repressão durante a Ditadura Militar.

\section{Os delatores na historiografia brasileira}

A proliferação de pesquisas nas últimas décadas ampliou significativamente os estudos sobre a ditadura militar no Brasil. Há uma historiografia bem diversa que perscrutou os episódios que levaram ao golpe, a conjuntura social e econômica do período, o governo de João Goulart, a montagem da estrutura legislativa da ditadura, o sistema de segurança e de informações, as engrenagens da repressão, a espionagem, a censura, a tortura, o exílio, as mortes e os desaparecimentos, bem como a resistência, tais como o movimento estudantil, a luta armada e a luta pela anistia e pela redemocratização. 
Tem se ampliado também os estudos regionais sobre a ditadura militar, sobretudo com as pesquisas realizadas nos Programas de Pós-Graduação em História. Evidentemente, ainda faltam alguns arquivos a serem mais vasculhados e analisados pelos pesquisadores, sobretudo aqueles fundos documentais que compõem o projeto "Memórias Reveladas" do Arquivo Nacional, os arquivos das polícias política estaduais (os famosos DOPS/DEOPS) e os documentos recolhidos pelas diversas comissões da verdade (nacional, estaduais, municipais, universitárias) que se instalaram no país a partir de 2012. Novos olhares sobre esses fundos documentais podem desvelar conhecimentos ainda não ressaltados ou que precisam ser ampliados.

Entre os temas que julgamos que precisam ser mais estudados estão os da delação espontânea e do papel dos informantes colaboradores ou duplos. A delação ainda é um tema aberto nas pesquisas historiográficas brasileiras. Afortunadamente, alguns trabalhos já trazem essas preocupações, mesmo que diluídas em textos mais abrangentes. É em meio a esse universo que procuramos delinear o presente estudo.

Um dos primeiros autores a se atentar para o tema foi Marion Brepohl (MAGALHÃES, 1997). Em artigo publicado na Revista Brasileira de História, ao fazer uma análise dos aparelhos repressivos da Ditadura Militar ${ }^{3}$, chamou a atenção para dois pontos: a) a existência do informante como colaborador espontâneo da polícia política; e b) o governo, através da sua rede de informações, garantia a invisibilidade e o anonimato desses colaboradores. Esse artigo teve importante repercussão na época em que foi publicado e ainda hoje serve como parâmetro para análises próximas. Marion Brepohl ainda voltou ao tema em outro artigo, publicado em 2009. Nele, a autora procurou analisar o comportamento concreto de alguns indivíduos que colaboraram voluntariamente para a vigilância e repressão exercidas durante a ditadura militar. Tomando como fontes algumas cartas de denúncias encontradas nos arquivos das polícias políticas (DOPS) do Brasil, Brepohl chamou a atenção para o fato de que, na maioria dos casos, esses

\footnotetext{
${ }^{3}$ Ressaltamos que o instituto da delação acompanha a história brasileira. Não é o caso aqui de dar exemplos, mas precisamos indicar que alguns trabalhos extemporâneos à ditadura militar são importantes para entender a questão da delação em conjunturas autoritárias. São os casos dos livros de Elizabeth Cancelli (1994) e de Marcos Tarcísio Florindo (2006).
} 
colaboradores tinham a mesma formação social ou profissional das pessoas denunciadas, e que essas pessoas eram sempre acusadas de serem inimigas radicais do governo militar e de colocar em risco a ordem social estabelecida (MAGALHÃES, 2009).

Carlos Fico (2002) também se utilizou das cartas encaminhadas por cidadãos, anônimas ou assinadas, à Divisão de Censura de Diversões Públicas (DCDP), órgão do Ministério da Justiça, para analisar a censura da produção cultural do período militar. Pesquisando a documentação da DCDP, depositada no Arquivo Nacional, encontrou aproximadamente 200 cartas enviadas ao órgão censor, questionando programas de TV, filmes, livros e revistas, que apresentavam algum conteúdo moral ou de costumes. Segundo o autor, boa parte dessas cartas solicitavam providências contra o que a TV exibia, como filmes violentos, menção às drogas, depreciação de algumas profissões, como por exemplo, mostrar enfermeiras retratadas como prostitutas ou professores de educação física descritos como simples cultivadores da boa aparência. No entanto, a maioria das cartas abordavam mesmo questões morais, relacionada à sexualidade, prostituição, libertinagem, pornografia etc. Fico republicou esse texto, com pequenas modificações, no livro Além do golpe, publicado em 2004 (FICO, 2012).

Recentemente, veio à luz o artigo de Janaina Martins Cordeiro (2019) que trata especificamente sobre o tema da delação. No artigo, analisa alguns casos da prática delatória no Brasil, durante a Ditadura Militar, buscando compreender as formas que cidadãos, geralmente informantes eventuais, passaram a recorrer ao Estado para delatar autoridades locais, vizinhos e colegas de trabalho. Esse caminho nos possibilita também compreender como a ditadura, a partir de uma linguagem própria e de um modus operandi específico, invadiu e moldou "aspectos diversos da vida cotidiana da sociedade brasileira" (CORDEIRO, 2019, p. 238).

Algumas dissertações e teses recentes também têm discutido o assunto. Daniel Trevisan Samways (2014), em sua tese, destaca que a Ditadura Militar, além de realizar forte divulgação do regime através de suas agências de propaganda, arregimentava informantes e colaboradores espontâneos que 
pudessem contribuir na vigilância da sociedade. Samways enfatiza a existência de três tipos de colaboradores: a) aqueles recrutados no serviço público; b) pessoas que eram membros de organizações próximas ao regime; e c) colaboradores espontâneos e voluntários que atuavam individualmente, mas que mantinham "vínculos ideológicos com o regime" ou ainda buscavam obter “alguma vantagem ou atingir um desafeto político" (SAMWAYS, 2014, p. 124).

No estudo que realizou sobre controle social no âmbito da educação superior, Jaime Valim Mansan (2014) constatou que, além dos informantes objetivamente vinculados ao Estado, que atuavam no processo de vigilância e controle social dentro das universidades, a ditadura contou também com colaboradores voluntários, geralmente reitores e outros dirigentes da estrutura burocrática universitária, que se utilizavam dos seus cargos para denunciar, aos órgãos de segurança, opositores ou desafetos. Essas delações geralmente eram motivadas "por afinidades ideológicas, por busca de vantagens ou em razão de divergências pessoais" (MANSAN, 2014, p. 109).

Reginaldo Cerqueira Sousa (2016) também dedicou algumas páginas de sua tese de doutorado para analisar o papel do informante e do colaborador do regime. Tomando como referências os estudos de Michel Foucault, Hannah Arendt e Pierre Ansart, Sousa analisa que o informante ou o colaborador constitui uma figura emblemática na cadeia do sistema repressivo brasileiro, pois a “compreensão de suas práticas" pode lançar luz ao rol de motivação que os levaram a "compactuar com determinadas forças de comando e sistemas políticos baseados na violência" (SOUSA, 2016, p. 111). Emblemática e complexa, pois diz respeito a um conjunto de aspectos psicológicos e subjetivos, já que tudo isso tem a ver com as "crenças, atitudes ou valores que impulsionam o indivíduo à ação e com as necessidades psicológicas que oferecem condições para que ele aceite uma ideia dessa natureza” (SOUSA, 2016, p. 111).

Foucault também serviu de inspiração para Marcília Gama da Silva (2007). Ao analisar a construção do estado de exceção no Brasil a partir da perspectiva do DOPS de Pernambuco, Silva percebeu que a ditadura militar articulou uma potente rede do sistema de informação, desde o SNI às Delegacias de Ordem Política e Social nos Estados, para organizar e implantar na sociedade um 
ambiente propício à colaboração de indivíduos com os órgãos de segurança. Nesse caso, a informação é vista como uma microfísica do poder, colocada em ação por aparelhos e instituições de estados, mas cujo "campo de validade se coloca de algum modo entre esses grandes funcionamentos e os próprios corpos com sua materialidade e suas forças (FOUCAULT, 1993, p. 29). Esse poder é exercido também, através das "denúncias anônimas, das delações, do repasse de informações relevantes, da colaboração com o regime e da vigilância que passa a ser comungada pelos órgãos, mas também pelos cidadãos" (SILVA, M., 2007, p. 64).

Uma das dissertações mais completas sobre o assunto é a de Rodrigo Pereira da Silva (2017). No estudo, Silva analisa a atuação e a colaboração dos informantes, voluntários ou profissionais, que tinham algum vínculo com a Delegacia de Ordem Política e Social do Paraná (DOPS-PR) no período da Ditadura Militar. O autor parte de uma hipótese simples, mas correta, de que a ação dos delatores gira em torno da influência exercida pelo imaginário anticomunista, propagado e disseminado tanto por setores civis quanto militares. Porém, Silva enfatiza que essas delações são movidas, muito mais, pelas paixões políticas do que propriamente por troca de interesses materiais, como dinheiro, facilidades para o exercício de certas atividades, promoção para algum cargo etc. Ao se apropriar do discurso anticomunista, os delatores acreditavam que através de suas denúncias conseguiam a manutenção da estabilidade da ordem pública, ao mesmo tempo em que preveniam a sociedade paranaense do perigo comunista.

Como se pode ver nos estudos citados, a historiografia recente brasileira ainda está debutando sobre o tema. Mas é alentador que alguns trabalhos já tenham jogado luz sobre o papel das denúncias e das delações, em particular, durante a ditadura militar. O esforço deste artigo é contribuir com o assunto.

\section{Delatores e sociedade na Ditadura Militar}

Para melhor esclarecer os leitores sobre a ação dos delatores e dos informantes colaboracionistas, restringiremos nossa análise ao ano de 1964 e a centraremos em três pontos ocorridos durante a operação limpeza: delações realizadas na cidade de Curitiba; as atuações desses colaboradores no interior 
do estado, para mostrar que as garras da vigilância estavam para além dos grandes centros; e por fim um caso de estrangeiro, que era bastante recorrente neste tipo de prática.

Em 15 de maio de 1964, o General de Brigada Dario Coelho, comandante da 5a Região Militar do Exército, com sede em Curitiba, recebeu uma longa carta, assinada por uma tal "Mme Felicidade", que se reconhecia como "brasileira e mãe" e que tinha, segundo ela, se perfilado ao lado "de outras patrícias, vigilantes, nos dias sombrios que nosso país atravessou, quando governado por irresponsáveis", numa referência evidente à sua participação nas Marchas da Família com Deus pela liberdade. "Madame Felicidade", logo no início de sua carta, enaltecia o papel dos militares e fazia um agradecimento a Dario Coelho, pela valorosa contribuição do general ao "movimento revolucionário" vitorioso em março de 1964. Como se considerava partícipe do "movimento vitorioso", se julgava também na obrigação de contribuir com o novo regime de alguma forma. "Agora que o exército brasileiro acrescentou à nossa história mais uma brilhante página, estamos também interessadas em contribuir para a 'consolidação e salvaguarda da democracia' e completa erradicação do comunismo". E sua contribuição vinha em forma de algumas denúncias, com o objetivo de "extirpar de vez a erva daninha" para semear uma "boa sementeira" nos novos tempos que se inauguravam com o golpe civil-militar (DEAP, Fundo DOPS, pasta 797.94, p. 105).

"Madame Felicidade" tinha pressa no fortalecimento desses novos tempos. Da mesma forma que enaltecia o novo governo, reclamava da lentidão das autoridades em tomar providências contra os chamados "inimigos" do regime. $\mathrm{Na}$ carta, ela deixava clara esta preocupação: "temos fornecido a várias autoridades de nossa cidade, uma lista de nomes, de alguns comunistas e, no entanto, estes indivíduos estão por aí, serenos e despreocupados, pois até agora, já passado quase dois meses do movimento revolucionário, não foram molestados".

$\mathrm{Na}$ carta, ela deixava transparecer certa desconfiança nas autoridades policiais subalternas e demonstrava um certo temor de que essas autoridades não cumprissem com o seu destino de limpar a sociedade. Enfática, evidenciava 
sua temeridade: "as autoridades a quem apelamos, não quiseram tomar conhecimento, o que muito nos tem intrigado, assim como a várias outras pessoas". Segundo ela, sua carta representava um sentimento coletivo, "de outras pessoas", "de outras patrícias", como destacou algumas vezes no texto.

Foi comum, durante a sua história, O DOPS receber informações de colaboradores, anônimos ou identificados. ${ }^{4}$ Logo após o golpe civil-militar, percebemos que o Exército também passou a ser uma instituição recorrente para o envio desses bilhetes e cartas. E como era de praxe, o comandante da 5 a Região Militar do III Exército, ao receber esses informes ${ }^{5}$, enviava-os à DOPS, para que aquela delegacia verificasse se tinha anotações sobre os acusados ou então para abrir investigações sobre os mesmos. Em ofício datado de 21 de maio de 1964, o comandante da 5ạ Região Militar do III Exército encaminhou ao DOPS uma lista com os nomes de nove pessoas para que o órgão policial pudesse averiguar a sua vida pregressa.

No ofício, o comandante ressaltava que os nomes haviam chegado até aquela Região Militar através de denúncias anônimas (DEAP, Fundo DOPS, pasta 797.94, p. 101). Nas denúncias, as informações praticamente se repetiam. As nove pessoas eram acusadas de serem comunistas, de distribuírem jornais, de fazer propagandas ou de possuir livros supostamente comunistas em suas residências. Diante dessas informações, em ato contínuo, o DOPS fez diligências sobre os acusados, apontando que dos nove "suspeitos", dois já eram fichados naquela Delegacia (DEAP, Fundo DOPS, fichas nominais 02.809 e 46.563).

\footnotetext{
${ }^{4}$ Cláudia Monteiro (2007, p. 102), analisando a experiência dos militantes comunistas entre os ferroviários de Curitiba, comenta sobre um indivíduo que se identificava com a letra "X", que recorrentemente escrevia ao DOPS, informando das atividades realizadas pela célula Olga Benário Prestes, do PCB, naquela cidade, entre os anos 1934-1945. Para a fonte, ver no DEAP, o Fundo DOPS (Pasta temática 264.29, p. 211-212). Outros casos semelhantes, no mesmo período, podem ser encontrados nas pastas 832.100, 833.101 e 834.101.

Em relação aos informes é pertinente salientar que também eram produzidos a partir de informações levantadas por agentes da polícia política, infiltrados nos grupos de esquerda. Por exemplo, no Informe n. 64-E/64, constavam informações de que o PCB pretendia realizar um atentado contra o comandante do III Exército. O Informen. 152-E2/65, remetido pelo comandante da 5a RM ao delegado do DOPS/PR, destacava que os comunistas usavam o teatro, as associações de classe e os centros culturais como canais para difundir ideologias exógenas. Em outro Informe, o de n. 75-E2/66, havia a afirmação de que o PCB furtaria as armas das Organizações Militares com o propósito único de preparação de guerrilhas (DEAP, Fundo DOPS, pasta 1465, s/p.). Portanto, a DOPS precisava estar atenta, vigiando e reprimindo os focos e as ações dos comunistas, e manter o comando da 5ạ RM sempre informado (BRUNELO, 2009).
} 
Um outro caso é da delatora que se intitulou "uma mãe e esposa brasileira”. Na sua carta manuscrita de duas folhas, enviada uma semana após o golpe (07/04/1964), ela indica um endereço na cidade de Curitiba (uma casa na rua Marechal Deodoro), dizendo que aquele local, antiga sede do Centro Popular de Cultura 6 , tinha se transformado em um "foco de comunistas [...] frequentados por estudantes e mulheres formadas em Filosofia” (DEAP, Fundo DOPS, pasta 797.94, p. 154-155).

A “mãe e esposa brasileira”, que na carta pede desculpas por não se identificar, por medo de que "abram no correio", ao que tudo indica, é moradora vizinha do endereço denunciado, pois a riqueza de detalhes com que ela descreve sobre a rotina do local é surpreendente e vale a pena destacar. Em um parágrafo diz: "Também há um carro Sinca de placa 1-56-30 que é da turma e vai seguidamente na referida casa e é guardado na garagem”. Em outro informa: "O homem que alugou a casa, não residia na mesma até hoje, porém hoje chegou com uma mulher e estão instalados nela. Dizem que ele é gaúcho e ela de Campo Grande". Ainda dá detalhes de outros moradores da casa: "Existem estudantes de engenharia que moram lá, um é japonês, mas há uns que não se sabe que é que são (sic), pois não parecem ser estudantes”. E por fim, comenta parte da rotina interna da casa: "O movimento era muito grande e passavam filmes, agora estão quietos, mas continuam a entrar e sair, mas agora só pelo porão, até ontem estavam na casa toda" (DEAP, Fundo DOPS, pasta 797.94, p. 154-155). A carta, plena de detalhes, chamou a atenção da direção do DOPS, que anotou: "é caso de investigação".

Uma outra moradora, que também declinou de se identificar por ser "visinha (sic) da comuna e não ficaria bem para mim", enviou uma carta datilografada à polícia política em 14 de abril de 1964. Nessa carta, a "vizinha da comuna" parabenizava o delegado do DOPS por sua brilhante ação anticomunista e pela "magnífica batida na residência da famigerada dona Mimi”. Mas a delatora não se contentava com a batida policial, porque "faltou a principal". E a "principal", segundo a "vizinha da comuna", era Alcina Silveira”, uma das líderes

\footnotetext{
${ }^{6}$ O Centro Popular de Cultura do Paraná (CPC/PR) é uma das organizações populares que o DOPS manteve em constante vigilância (DEAP, Fundo DOPS, pasta 212.24).

Alcina Silveira ou Alcina Chamine da Silveira teve seu primeiro registro no DOPS/PR em
} 
do Movimento das Donas de Casa contra a Carestia. E enfatizava: "Principal, ainda, porque é comunista fanática, considerada entre os vermelhos como doutrinadora de primeira grandeza, participou ativamente na retirada dos documentos comprometedores da sede do Partido no Jornal Novos Rumos, levando grande parte para a sua residência, que fica na rua Dr. Murici” (DEAP, Fundo DOPS, pasta 797.94, p. 156).

Um ponto convergente entre os vários delatores anônimos, ou mesmo entre os que assinavam as colaborações, era o elogio às autoridades policiais. No caso da "vizinha da comuna", que vimos acima, ela reconhecia que o Delegado do DOPS, Miguel Zacarias realizava um brilhante trabalho frente àquela Delegacia e na repressão aos comunistas. O mesmo procedimento tomou E.J.M., em carta endereçada no dia 24 de novembro de 1964, ao Secretário de Segurança Pública do Estado do Paraná, Ítalo Conti. Na carta, o delator elogiava o Secretário de Segurança, reconhecendo que este teve "magnífica atuação durante os primeiros dias da Revolução no trato com os inimigos da Democracia" (DEAP, Fundo DOPS, pasta 797.94, p. 177). Entretanto, mesmo com o elogio, E.J.M. demonstrava certa preocupação com o futuro da ação das forças repressivas: "Infelizmente, a Revolução está tendendo a 'amolecer' a sua linha de ação contra os comunistas, e eles já começaram a levantar a cabeça”.

O missivista fazia referência ao funcionamento de uma livraria, denominada Livraria do Povo, que estava fazendo liquidação de livros e que, segundo ele, essa literatura era "podre, subversiva e caluniosa". E para combater a venda desses livros na livraria citada, solicitava que a polícia tomasse "as providências cabíveis ao caso, em defesa da nossa Revolução. Espero que tais livros sejam imediatamente apreendidos e destruídos pela polícia, a fim de não contaminarem ainda mais o espírito dos inocentes úteis de Curitiba”. E terminava sua carta, mais uma vez apelando ao Secretário de Segurança Pública, que para a continuidade da revolução Moralista, que estava sendo levada à cabo no país, era necessário dar continuidade à atuação eficaz que ele teria colocado em prática nos primeiros dias de abril daquele ano.

16/12/1950 e a última anotação em sua ficha foi em 17/12/1971 (DEAP, Fundo DOPS, ficha nominal 41.463). 
Eram constantes também as denúncias contra pessoas sobejamente conhecidas do cenário político do Estado, como é o caso de José Rodrigues Vieira Netto. Advogado e professor da Universidade Federal do Paraná, Viera Netto era uma personagem bastante conhecida no Estado do Paraná. Advogado "brilhante", um "sujeito de grande cultura" e que tinha um "dote oratório pelo próprio fato de ser advogado" - constatou Milton Ivan Heller (2008, p. 107). Vieira Netto foi candidato a Deputado Federal pelo Partido Comunista Brasileiro (PCB) em 1945, não logrando se eleger. Mas, dois anos depois, foi eleito Deputado Estadual Constituinte no Estado do Paraná, pelo PCB, no breve interregno de legalidade daquele partido. E a partir daí participou das mais diversas lutas sociais do Estado do Paraná e na direção clandestina do PCB, o que the tornou figura muito conhecida nos órgãos de segurança do Estado, sendo que sua ficha no DOPS é uma das mais extensas entre os militantes comunistas fichados. ${ }^{8}$

Numa das denúncias contra Vieira Netto, o anônimo delator, ao dirigir-se ao chefe do DOPS, registra: "É obrigação de todos os cidadãos colaborar com o Sr., na tarefa de reprimir o comunismo". E indica que o desmantelamento da atuação dos comunistas do Paraná "torna-se incompleto [...] enquanto não for neutralizado o Dr. Vieira Neto" (DEAP, Fundo DOPS, pasta 797.94, p. 65), dando mostras de que o colaborador da polícia política sabia da importância e do papel exercido pelo velho militante comunista na resistência à ditadura militar que se iniciava.

Essas dúvidas em relação à atuação das autoridades policiais foram questionadas por outros colaboradores. Em documento sem data, mas arquivado no DOPS, no mês de outubro de 1973, um colaborador que se identificou como um "bom brasileiro", reclamava da ineficiência da polícia do Estado do Paraná, que segundo ele, havia se transformado em uma "polícia de costumes" e servia apenas para prender "mulheres da vida", enquanto não se fazia nada para as "outras barbaridades que andam por ahí". O informante não 
especificava quais eram estas "outras barbaridades", embora deixasse transparecer seu incômodo com "esse sistema abominável” existente e com certas notícias "pouco recomendáveis" que eram publicadas nos rádios e nos jornais. No final da sua carta, enfatizava: "a revolução foi feita para corrigir, devemos fazer o possível, para chegar nessa meta” (DEAP, Fundo DOPS, pasta 797.94, p. 65).

Essa mesma preocupação encontramos nos informes de E.F.G., que denunciavam várias casas noturnas, locais ideais para o uso de drogas e de prostituição (DEAP, Fundo DOPS, pasta 798.94, p. 11). Não é de todo sem sentido as reclamações dos informantes, pois durante as décadas de 1970 e 1980, a Ditadura Militar solidificou todo um aparato repressivo em defesa da moral e dos "bons costumes", sobretudo na repressão às prostitutas e aos homossexuais (QUINALHA, 2017). No Estado do Paraná, desde o ano de 1956, a Secretaria de Segurança Pública havia criado a Delegacia de Costumes (Decreto No. 7250, de 15 de dezembro de 1956) com o objetivo de investigar, prevenir e reprimir a prostituição, evitando que afetassem a moralidade pública, as ações que pudessem afetar a honra e a dignidade das famílias, as manifestações que contrariassem a moral e os bons costumes, além da venda e exposição de livros, desenhos e gravuras que ofendessem a moral (ROLIM, 2000).

No interior do Estado, a maior preocupação dos delatores era com as questões rurais. Uma das cartas mais significativas que encontramos na documentação do DOPS foi escrita pelo vigário de Santa Amélia (pequena cidade da região norte do Paraná) com data de 07 de maio de 1964. Em carta dirigida ao governador do Estado e depois encaminhada ao DOPS para providências, o padre enfatiza que sua carta é para protestar contra a "liberdade que se encontram os inimigos da democracia”. E cita três vereadores da cidade que, segundo sua delação, eram adeptos das ideias de Brizola e de Jango e que faziam "rasgados elogios dos comuno petebistas (sic) e isto com a complacência do prefeito". Dizendo-se ameaçado de morte, o padre estava indignado que, depois de quase 40 dias do golpe, as pessoas por ele citadas ainda estavam à frente do município.

Na carta, o vigário de Santa Amélia ainda reclamava da atuação do delegado da cidade, que não ficava o tempo todo na localidade, e com isso 
"comunistas declarados" continuavam andando de "cabeça erguida" por todos os lugares. E sugeria ao governador que trocasse imediatamente $\mathrm{O}$ atual delegado, por outro "bom delegado ou mesmo agente do DOPS". O padre ainda oferecia hospedagem em sua casa aos agentes do DOPS. Na conclusão de sua missiva, cobrava: "limpe por amor de Deus Santa Amélia. Acabe com os comuno petebistas daqui. Mande cassar os mandatos e colocar na cadeia esta gente, é uma grande obra de misericórdia" (DEAP, Fundo DOPS, pasta 797.94, p. 92-94).

A indignação demonstrada pelo vigário de Santa Amélia com a complacência de autoridades locais com supostos militantes comunistas não era isolada. Na cidade de Ibaiti (região norte do Paraná), trabalhava na delegacia local o Sub-Tenente Augusto da Silva. No ano de 1966 ele foi transferido para a localidade de Harmonia, distante aproximadamente $85 \mathrm{~km}$ de Ibaiti. A transferência do Sub-Tenente não foi vista com bons olhos por um cidadão local.

Em carta anônima, dirigida ao próprio Sub-Tenente Augusto da Silva e deixada em baixo da porta da Sub-delegacia da localidade de Harmonia, o missivista fez diversos elogios ao destinatário: "amigo sargento as coisas aqui não está (sic) boa, os comunistas depois que você saiu daqui estão agindo, quando você estava aqui eles tinham medo do senhor [...] o único homem que pode denunciar esses bandidos vermelhos é o senhor" (DEAP, Fundo DOPS, pasta 797.94 , p. 114). Na sequência, o colaborador anônimo da polícia vai detalhando e denunciando algumas situações relevantes, embora não haja nos documentos pesquisados dados que possam confirmar as acusações. A maior preocupação é com a presença dos supostos comunistas na cidade. Na carta, ele informa que um "amigo" de nome Jonas foi morto na cidade, "a mando dos vermelhos"; que os comunistas se "reúnem pelos sítios e [...] na cidade"; que a cidade de Ibaiti estava servindo para "campo de ação para estes bandidos traidores e vingativos"; e que um "amigo de [João] Goulart, veio para Ibaiti, como tomador de terras, e agora é dono de Cartório" (DEAP, Fundo DOPS, pasta 797.94, p. 114). Como se vê, o rol de denúncias é amplo e diverso. E o delator termina sua carta fazendo um apelo muito próximo do que solicitou o vigário de Santa Amélia, apelando "pelo amor de Deus que mande esta carta para as autoridades de Curitiba" (DEAP, Fundo DOPS, pasta 797.94, p. 114). 
As cidades de Ibaiti e Santa Amélia ficam localizadas na região denominada no Paraná como Norte Pioneiro. Nessa região, os comandos nacionalistas, também conhecidos como Grupo dos Onze Companheiros tiveram forte presença. Criado no final de 1963, por Leonel Brizola, o Grupo dos Onze tinha como missão reivindicar junto ao governo de João Goulart a imediata realização das reformas de base, a luta contra o imperialismo e defesa da democracia. Como o nome indica, era formado por onze companheiros, que se reuniam uma vez por semana, geralmente às sextas-feiras à noite, quando Leonel Brizola transmitia seus famosos discursos pela Rádio Mayrink Veiga.

Luana Pradela (2019, p. 85 e ss.) identificou, na sua pesquisa realizada com a documentação do DOPS, mais de 60 grupos no Paraná, sendo 14 só na região do Norte Pioneiro. No Paraná, a grande maioria desses grupos foram constituídos no campo, já que entre as reformas de base, o tema da reforma agrária era o que mais galvanizava interesse e disputas políticas (REGGIANI, 2015).

Embora esses grupos não tenham tido uma ação prática mais eficaz, a documentação do DOPS (DEAP, Fundo DOPS, pasta 1084.131) demonstra que a polícia política fazia um constante monitoramento dos G-11 e depois do golpe de 31 de março de 1964, prendeu a maioria das lideranças que o integravam ${ }^{9}$. Para a polícia política, esses grupos eram tratados como células comuno-petebistas, o que de certa forma contribui com a confusão apresentada pelos delatores acima, confundindo muitas vezes os participantes do Grupo dos Onze com militantes comunistas.

A questão da terra sempre foi um problema grave e belicoso na história do Paraná. Há centenas de pastas no arquivo do DOPS. Alguns conflitos de terras marcaram a história do Estado bem como a história do Brasil. Três deles se destacam: a guerra do Contestado (MACHADO, 2004), a revolta de Porecatu (PRIORI, 2012) e a revolta do Sudoeste (AMANCIO, 2009; KOLING, 2018). Outros conflitos de menor intensidade têm sido objetos de pesquisas nos programas de pós-graduação, o que tem demonstrado a dimensão do problema. Esses

\footnotetext{
9 Vários integrantes do Grupo dos Onze prestaram depoimentos à Comissão Estadual da Verdade
} do Paraná. Alguns desses depoimentos foram publicados por Carla Silva e Alfredo Batista (2016). 
conflitos de terras tornaram-se referências para a atuação de partidos e movimentos políticos no campo. Um deles foi a atuação do Partido Comunista Brasileiro (PCB) na organização da revolta de Porecatu e na sindicalização rural (PRIORI, 1996, 2012).

A Igreja Católica também teve papel considerável, principalmente na organização sindical (ALVARENGA, 2008; BRITO, 2015). O Grupo dos Onze foi outro movimento, como vimos acima, influenciado pela atuação de Leonel Brizola, que teve forte presença no Paraná. E, durante a Ditadura Militar, pelo menos três organizações revolucionárias tentaram montar campos de guerrilha rural no Estado: o Movimento Revolucionário 8 de Outubro (MR-8), a Vanguarda Popular Revolucionária (VPR) e a Vanguarda Armada Revolucionária Palmares - VAR Palmares (CAMPOS, 2014; HERLER, 2015).

Um personagem persistente nas denúncias e nas delações dos colaboradores da polícia política é o estrangeiro. Líderes operários anarquistas e comunistas, de origem europeia, sempre foram vigiados ou denunciados aos órgãos policiais, desde o final do século XIX. Mas foi durante o Estado Novo, e mais especificamente a partir do Brasil aderir aos aliados durante a Segunda Guerra Mundial, que os estrangeiros, sobretudo alemães, japoneses e italianos se tornaram alvos constantes da polícia política. Márcio José Pereira (2017, p. 217 e ss.) relata diversos casos de alemães que foram denunciados à polícia, por delatores populares, pelo simples fato de serem vistos falando o idioma alemão na rua. Nos arquivos do DOPS/PR há uma imensidão de documentos recolhidos nas casas de poloneses e ucranianos, por exemplo. ${ }^{10}$

"Madame Felicidade", que já apresentamos acima, preocupada que o golpe instaurado em 1964 obtivesse êxito, na longa carta que enviou ao General de Brigada Dario Coelho, comandante da 5a Região Militar, apresentou uma lista de nomes de "comunistas" que "estão por aí, serenos e despreocupados". E em poucas linhas, retratou um desses indivíduos denunciados:

\footnotetext{
10 Desde o final do século XIX houve uma intensa imigração de poloneses e ucranianos para o Estado do Paraná. Esses grupos se radicaram na capital e no seu entorno e, também, na região dos Campos Gerais. No século XX foram constantemente monitorados pelo DOPS.
} 
É um comerciante estrangeiro, que nos dias áureos [...] do governo deposto, agia abertamente, vendendo ou presenteando sua freguezia com o jornaleco "Novos Rumos"; quis organizar um sindicato comunista das empregadas domésticas em nossa Capital; conferenciou com Luis Carlos Prestes, quando da última visita deste à nossa cidade; mandou seu filho fazer uma prévia na sua classe, em um dos grupos escolares daqui, cujo resultado o menino deu ao pai dizendo que sua sala, dos 36 alunos, só 3 eram reacionários. (DEAP, Fundo Dops, pasta 797.94, p. 105)

Como se percebe, "Madame Felicidade" tinha relações muito próximas com o comerciante estrangeiro, ou por ser sua cliente, ou por ser sua vizinha, pois a riqueza de detalhes que ela expressa em sua carta é impressionante. Mas a missivista não se contentava em fazer apenas a denúncia. Muito provavelmente incentivava outras pessoas a denunciarem o estrangeiro também, pois segundo ela:

Um amigo nosso telefonou ao DOPS também denunciando este comunista, e a resposta daquele Departamento foi que não dispunha de condução para atender, naquela hora. Nosso amigo, então, pôs à disposição daquela Delegacia, um dos seus veículos e nem assim foi tomada uma providência. É preciso não esquecermos que se o golpe viesse do lado de lá, talvez o "paredon" nos recebesse no dia seguinte. (DEAP, Fundo DOPS, pasta 797.94 , p. 105) $)^{12}$

E como não estava satisfeita com a atuação do DOPS, ainda perguntou ao comandante da 5a Região Militar, finalizando a sua carta: "E porque essa benevolência com essa gente?”.

Teremos mais detalhes sobre as atividades do estrangeiro a que se refere "Madame Felicidade" em outras duas denúncias realizadas diretamente ao DOPS, datadas de 16 de abril e de 22 de abril de 1964. As duas denúncias anônimas devem ter sido realizadas por uma mesma pessoa (provavelmente a tal Madame Felicidade ${ }^{13}$ ), pois as cartas são datilografas e são idênticas na letra e na forma da escrita. A partir dessas cartas, ficamos sabendo que o estrangeiro delatado era Bogdan Bogusiak ${ }^{14}$, residente na rua 13, no bairro Barreirinha, em Curitiba. Na primeira carta, de 16 de abril, assim se referia:

\footnotetext{
${ }^{11}$ Manteve-se a grafia do original.

12 Manteve-se a grafia do original.

13 Como ela confessa na delação que fez ao comandante da 5a Região Militar, Dário Coelho, tem enviado listas de nomes de comunistas a várias autoridades.

14 Na documentação do DOPS não aparece nenhuma informação sobre a sua nacionalidade.
} 
Há muito tempo que o mesmo está frequentando as reuniões dos comunistas, possue muitos livros [...] e também convida muita gente para assistirem estas reuniões. Há muito tempo que este homem vem prometendo matar gente, diz que apenas está esperando a hora, diz que vae acabar com a Democracia e com os sacerdotes, que isso não precisa existir [...]. Dizia o mesmo que depois que terminou a guerra na Alemanha, êle com mais 3 companheiros mataram muita gente, até as crianças dos berços. (DEAP, Fundo DOPS, pasta 797.94, p. 107)

E na segunda carta, de 22 de abril, voltava aos mesmos argumentos:

Podemos assegurar a V. Excia. que o Bogdan é um comunista e que desde que mora nesta Capital o mesmo vem prometendo queimar as casas, matar gente, cortar a cabeça fóra do corpo, quebrar os braços, pernas etc. e ainda diz que apenas está esperando a hora que precisa acabar com esta gente, com a Democracia. Sendo que a partir de 10. de abril o mesmo deixou de trabalhar, permanecendo em sua residência, armado e torcendo as mãos, dizia, agora está chegando a minha hora vou começar de matar do mais velho ao mais moço, vou fazer o mesmo o que fiz na Alemanha com os meus colegas logo após a guerra. (DEAP, Fundo DOPS, pasta 797.94 , p. 108 $)^{16}$

Acreditamos que o DOPS não tenha dado muita importância para essas denúncias, pois não há registro de que o tal Bogdan Bogusiak tenha sido investigado ou preso. Pelo menos, na documentação do DOPS, não localizamos nenhuma pasta individual ou ficha nominal em seu nome. Em outro documento, há uma denúncia contra um tal M. Felipedes, de origem grega e tachado de agente de Moscou, "proprietário da casa de Carnes A Democracia”, que distribuía o jornal Novos Rumos, era acusado de querer "fundar nesta capital o sindicato das empregadas domésticas" e de ter se encontrado com "Luis Carlos Prestes no sindicato do edifício Mauá" (DEAP, Fundo DOPS, pasta 797.94, p. 102). Não foi possivel saber se os dois denunciados eram a mesma pessoa, embora as informações sejam coincidentes. M. Felipedes também não foi fichado no DOPS/PR.

\footnotetext{
${ }^{15}$ Manteve-se a grafia do original

${ }^{16}$ Manteve-se a grafia do original
} 


\section{As práticas da delação}

A narrativa documental das delações que detalhamos no tópico anterior nos leva a fazer algumas reflexões. A primeira delas é pensar a prática da delação. $\mathrm{Na}$ linguagem jurídica, delatar é diferente de denunciar. Uma denúncia geralmente é uma peça acusatória que inicia um processo judicial. Atualmente é apresentada pelo Ministério Público e que leva ao conhecimento do Poder Judiciário um ato delituoso ou criminoso. No limiar da Ditadura Militar, quando foram instaurados os primeiros Inquéritos Policiais Militares para julgar casos de infração aos dispositivos da Lei de Segurança Nacional, a denúncia era realizada por um promotor militar, que remetia à Justiça Comum, até 27 de outubro de 1965, quando por força do Ato Institucional № 2 (Al-2), os mesmos passaram a ser remetido para a Justiça Militar (ARNS, 1985, p. 170 e ss.).

Já a delação é diferente. No Brasil atual, o tema das delações, sobretudo as delações premiadas, tem ganhado cada vez mais espaço de discussão, tanto na imprensa como na sociedade. O tema ganhou relevância, principalmente, a partir da nomeada Operação Lava Jato, mecanismo da Polícia e da Justiça Federal para investigar lavagem e desvio de dinheiro público. Juridicamente, a delação foi instituída, através da Lei №. 8.072, de 25 de julho de 1990, que ao regulamentar o crime hediondo, também permitiu ao participante ou ao associado de alguma quadritha ou de organização criminosa, denunciar à autoridade um ou mais membros, que permitisse ao Estado desmantelar a organização, e com isso teria a sua pena reduzida. Mas não é o caso aqui. Delatar, como nos exemplos que estudamos acima, é um ato geralmente individual, espontâneo, de um cidadão comum, que comunica ao Estado um certo delito, apontando algumas especificidades ou evidências e solicita que se aplique alguma pena, geralmente a prisão. A delação é uma denúncia interessada, por mais perversa e desprezível que possa ser. Embora, quando um delator se dirija a uma autoridade policial, ele esteja movido das suas melhores intenções (CORDEIRO, 2019; JOLY, 2012).

Marion Brepohl caracterizou os delatores como "homens comuns, sem nenhum comprometimento formal com o sistema, mas que enviavam cartasdenúncias ao DOPS sobre quaisquer pessoas ou movimentos, entendido por eles 
como suspeitos de subversão" (BREPOHL, 2012, p.145). Gellately (2011), ao analisar a relação das pessoas comuns com o nazismo indaga: por que tanta gente colaborou com o regime? E muitas vezes, esse apoio não se dava, necessariamente, por questões ideológicas, mas sim, por motivos pessoais egoístas, às vezes até por denúncias falsas, com o objetivo de resolver disputas pessoais, conflitos familiares, rivalidades e desavenças no trabalho, entre outras questões, geralmente para obter algum benefício material ou social.

Gellately classificou esse movimento como uma "manipulação do sistema desde abaixo", ou seja, uma parte da população percebeu que podia utilizar do sistema de terror para o seu próprio benefício. Era uma "cumplicidade quase ubíqua", como ressaltou Hannah Arendt no seu Eichmann em Jerusalém. Ao explicar o porquê cunhou o termo "banalidade do mal", Arendt descortinou para seus leitores um fenômeno que acompanha os historiadores e os cientistas sociais que estudam ditaduras e regimes totalitários. Eichmann não era nenhum Macbeth. "A não ser por sua extraordinária aplicação em obter progressos pessoais, ele não tinha nenhuma motivação" (2007, p. 310). Assim mesmo Eichmann foi o responsável pelo transporte de milhões de judeus rumo aos guetos e aos campos de extermínio. Mas Arendt vai além: "Para falarmos em termos coloquiais, ele simplesmente nunca percebeu o que estava fazendo" (2007, p. 310, grifo do autor). Qual o espaço do banal, do trivial, do lugar comum nestes regimes, totalitários ou ditatoriais? Por que o cidadão comum faz denúncias, delata ou participa de atos criminosos contra pessoas, geralmente inocentes?

Esses estudos desmistificam a imagem de que as pessoas comuns eram vistas, quase sempre, como personagens da resistência e da oposição ao regime. Pelo contrário, tanto nos regimes totalitários como nas ditaduras militares latinoamericanas, estudos recentes têm demonstrado que houve uma impressionante colaboração de amplos setores da sociedade que podem ser categorizados como "cidadãos comuns".

Nos estudos de Sheila Fitzpatrick e Robert Gellately (1996a; 1996b), eles já haviam indicado que as práticas da delação são comuns em aproximadamente todas as sociedades organizadas. Porém, fazem a ressalva de que em algumas 
delas, ou em momentos históricos distintos, essas práticas podem ser mais ou menos difundidas, dependendo de uma série de fatores e de tradições políticas e culturais e, obviamente, do grau de encorajamento por parte do Estado. Para os autores, tais práticas são como um elo de referência entre os cidadãos e o Estado.

As delações que estamos estudando são dirigidas ao Estado, mas contra pessoas consideradas inimigas do povo ou da Nação (como são os casos das acusações contra Bogdan Bogusiak, José Rodrigues Viera Netto, Alcina Silveira e os três vereados da cidade de Santa Amélia) ou contra grupos estigmatizados (como os estudantes e as mulheres que se reuniam na casa da rua Marechal Deodoro, as prostitutas, o Grupo dos Onze Companheiros e os comunistas, de forma em geral).

Se no Brasil os estudos históricos sobre delações ainda são raros, já existe uma historiografia bastante consolidada em outros países da América e da Europa. E todos esses estudos têm confluído para uma ideia de que a delação foi um importante mecanismo para a estruturação dos diversos regimes ditatoriais e totalitários, já que as práticas acusatórias revelam não só a conveniência pessoal de quem delata, mas também proporcionam que os Estados ampliem as suas medidas de repressão. Alguns exemplos.

Robert Gellately, no seu livro Apoiando Hitler(2011), mas em outros estudos também, tem sustentado que as delações tiveram considerável importância nas ações da Gestapo e no funcionamento do sistema de terror adotado na Alemanha nazista. Na Espanha franquista, o Estado amparou e impulsionou o exercício da delação, sobretudo de cidadãos comuns, nas grandes cidades, mas também nas pequenas localidades rurais, com o objetivo de localizar e de punir anarquistas, comunistas e guerrilheiros que sobreviveram aos horrores da Guerra Civil Espanhola. Ángela Cenarro (2002) ressalta que as delações serviram para azeitar a solidificada máquina repressora do regime, mas também para montar as bases das futuras acusações e dos processos judiciais instaurados durante e depois da guerra, contra os chamados "perdedores", ou seja, os republicanos.

Essas práticas delatoras se espalharam por toda a Espanha, embora se possa verificar que tiveram resultados devastadores na Catalunha, seja no campo 
e nas pequenas localidades rurais (CURCÓ, 2000a; 2000b) ou nas grandes cidades como Barcelona (FABRE, 1984). Em Barcelona, por exemplo, o Tribunal Regional de Responsabilidades Políticas divulgava nos jornais o endereço e o horário de atendimento do órgão, incentivando as pessoas a fazerem denúncias contra os inimigos do regime. Essa mesma evidência vamos encontrar na Argentina, durante a última ditadura militar (1976-1983). Daniel Lvovich (2017) reforça que a ditadura militar argentina, obviamente, não precisou das delações para montar os modos mais cruéis da repressão, como foram as detenções, os desaparecimentos e os assassinatos, mas se utilizou dessas práticas para obter as informações necessárias para os mais diversos serviços de inteligência militares e policiais.

E no Brasil? Obviamente, o instituto da delação não é uma característica singular da ditadura militar. Temos exemplos ao longo da história. Dois casos históricos de delatores ganharam certa repercussão política e historiográfica: Domingos Fernandes Calabar, que em 1632, desertou das fileiras portuguesas e se juntou aos holandeses, facilitando assim, o processo de ocupação de Pernambuco. "Homem muito ativo e inteligente" - escreveu Boxer (1961, p. 70-71) - "não poderiam os holandeses ter achado melhor guia e informante para indicar os pontos fracos do inimigo"; e Joaquim Silvério dos Reis, que durante a Inconfidência mineira, delatou para o Visconde de Barbacena, então governador de Minas, os seus colegas conjurados, sonhando com "dinheiro, mercês, comendas", como cravou Cecília Meireles no seu Romanceiro da Inconfidência (MEIRELES, 1989). Em defesa de Calabar, registramos que, ao contrário de Joaquim Silvério, parece que não foi por "interesse pecuniário" que ele desertou, pois ele achava que "Os holandeses fossem melhores para o Brasil" (SOUZA, 2004, p. 504), embora isso não esteja claro na historiografia sobre o tema.

Mas foi a partir do Governo Vargas, com o fortalecimento e a estruturação da polícia política, que o governo criou diversos instrumentos de propaganda, com o objetivo de fazer com que a população se sentisse engajada na construção de um novo país e que criasse um "sentimento de regeneração nacional" (CANCELLI, 1994, p. 47). 
Durante essas campanhas, os comunistas se tornaram os alvos preferenciais de perseguição e de repressão do Estado e a delação se tornou uma das "formas de engajamento participativo muito estimulada pelas autoridades" (CANCELLI, 1994, p. 93). Constituía-se "ato de bravura" entregar um comunista à polícia. Essas campanhas foram se fortalecendo, sobretudo a partir de 1935 e atingiram o seu auge com a criação da primeira Lei de Segurança Nacional e depois com o golpe do Estado Novo. Já no Estado Novo, quando o Brasil entrou na guerra ao lado dos aliados, os estrangeiros também se tornaram alvos de delação, sobretudo os alemães, os italianos e os japoneses.

Desde Vargas, portanto, a polícia política passou a ser a "sentinela avançada da ordem" (APOLONIO, 1954) e criou ampla rede de espionagem, utilizando seus agentes profissionais, mas também "colaboradores voluntários" que passaram a "vigiar" companheiros de organização, vizinhos, lugares públicos etc. como bem demonstrou Tarcísio Florindo em seu importante trabalho sobre o DOPS/SP (FLORINDO, 2006). Problematizando a questão do controle social, Florindo enfatiza as necessidades que as elites e o Estado tinham em transformar a agência policial em uma grande rede de vigilância do tecido social. E para um bom funcionamento dessa rede, ela dependia da "utilização de agentes não ligados oficialmente à burocracia estatal” que, espalhados pelos "recantos da sociedade, pudessem funcionar como informantes do órgão, avisando e prevenindo sobre os delitos e apontando os suspeitos e responsáveis" (FLORINDO, 2006, p. 33). Segundo o autor, a delação era um alicerce para os "trabalhos desenvolvidos pela agência responsável pela repressão política e social" (FLORINDO, 2006, p. 99) e que os motivos da delação eram geralmente por questões pessoais e ideológicas, que muitas vezes se misturavam (FLORINDO, 2006, p. 129). Na visão da polícia, através dessas denúncias, o cidadão ou a cidadã que fazia uma delação, além de se sentir útil, expressava um arraigado senso de patriotismo e de nacionalidade.

O incentivo de que a população participasse como colaboradora do regime é uma norma espraiada em todos os órgãos de segurança e foi amplamente utilizado pela Ditadura Militar. Marcília Gama da Silva (2007, p. 65) observou que nos registros policiais do DOPS de Pernambuco existiam documentos que 
conclamavam as pessoas comuns a colaborar com aquele órgão, pois a delação deveria ser uma "tarefa de todos", como enfatizava um prontuário interno daquele órgão. E a população atendia o chamado. Silva analisa a carta de uma mãe, cuja filha era aluna de medicina da Universidade Federal de Pernambuco (UFPE), denunciando os responsáveis por um panfleto distribuídos aos estudantes, no ano de 1973, que criticava o governo Médici, cobrava o fim do ensino pago nas universidades e denunciava os abusos cometidos contra populações rurais, na construção da rodovia Transamazônica: "Como não quero que futuramente minha filha seja influenciada pelas ideias aqui expostas, venho por meio desta, alertar as autoridades para o foco pernicioso que ali está se instalando" (SILVA, M., 2007, p. 65).

Marion Brepohl também detectou esse movimento organizado pelos órgãos de segurança e disseminado pelo DOPS do Paraná, através de propaganda, geralmente de caráter restrito, e dirigida a uma "pequena parcela da população por meio de documentos sigilosos, que eram dados a conhecer segundo a confiabilidade que o regime dispensava aos receptores, e que possuía uma finalidade mais organizativa" (MAGALHÃES, 1997, p. 209).

Em 1969, O II Exército ${ }^{17}$ produziu um documento Intitulado Decálogo da Segurança. Este documento foi distribuído pelo Serviço Nacional de Informações (SNI) para todo o todo o sistema de informações, com a recomendação de que fosse realizada "ampla difusão e distribuição do mesmo" (DEAP, Fundo DOPS, pasta 1870.213 , p. 119). Nesse documento, que posteriormente foi publicado em forma de panfleto, o II Exército elaborou um roteiro de dez pontos alertando a população para ficar atenta contra os "inimigos do regime". Para efeito da nossa discussão, apresentamos os pontos 1 e 9 :

1: Os terroristas jogam com o medo e o pânico. Somente um povo prevenido e valente pode combatê-los. Ao ver um assalto ou alguém em atitude suspeita, não fique indiferente, não finja que não viu, não seja conivente, avisa logo a polícia. As autoridades the dão todas as garantias, inclusive do anonimato. (DEAP, Fundo DOPS, pasta 1780.213 , p. 121)

\footnotetext{
Na época, o II exército compreendia os Estados de São Paulo e Mato Grosso, integrado pelas 2a e 9a Regiões Militares.
} 
9. Quando um novo morador se mudar para o seu edifício ou para o seu quarteirão, avise logo a polícia ou o quartel mais próximo. As autoridades the dão todas as garantias, inclusive do anonimato. (DEAP, Fundo DOPS, pasta 1780.213, p. 122)

Na lógica da polícia política, todo indivíduo, até que se prove ao contrário, é um suspeito. E como suspeito, a população também precisa exercer a constante vigilância, harmonizando-se com o Estado nessa função. Foucault, ao tratar do poder disciplinar, enfatiza que o poder tem a "função maior de adestrar ou adestrar para melhor retirar e se apropriar" (FOUCAULT, 1993, p. 29) de indivíduos ou de parte da sociedade. De certa forma, os órgãos de segurança estabeleceram essa relação com a sociedade em diversas conjunturas, como no caso da Ditadura Militar e já apontado por Marcília Silva (2007), algumas laudas acima. No caso dos delatores, eles podem ser observados, na linguagem de Foucault, como corpos adestrados em benefício da ordem e da segurança do país. As Cartas e os bilhetes, como vimos no terceiro tópico, podem ser definidos como uma mentalidade da informação, ou como um tipo específico de poder, já que o ato de informar pode ser caracterizado como uma forma de exercer, perante a sociedade, um comportamento vigilante, que torna o informante um sujeito participante da manutenção da ordem.

Uma das práticas mais recorrentes da delação é o anonimato. No Decálogo da Segurança elaborado pelo II Exército e ao qual nos referimos acima, ao final de cada item era reforçada a expressão: "As autoridades the dão todas as garantias, inclusive do anonimato". De certa forma, essa indicação reforçava a prática da delação, já que o delator se sentia seguro pelo exercício do anonimato e da segurança que não seria descoberto pelos delatados e autoridades. Mas não era uma questão tranquila para eles. Vejamos.

Na carta que a mãe de uma estudante de medicina enviou ao DOPS/PE, conforme analisou Marcília Gama da Silva, encontramos a justificativa da delatora: "Como se trata de assunto sigiloso e perigoso, não posso revelar minha identidade, mesmo fazendo com respeito à minha filha, pois poderia sofrer consequências funestas, caso descobrissem que ela é minha filha e que eu os denunciei" (SILVA, M., 2007, p. 66). 
Nos exemplos dos delatores do Paraná, que estamos analisando, quase todos vão ao encontro dessa ideia. A “mãe e esposa brasileira” diz que não pode se identificar por medo de que abram a carta no correio. A "vizinha da comuna" não se identificou pelo temor de que "não ficaria bem para mim". A maioria utilizava pseudônimos, como a "a mãe e esposa brasileira"; a "brasileira e mãe" ou o "bom brasileiro". Outros não se identificavam. E uma minoria assinava a denúncia, embora não tenhamos certeza de que esse fosse o seu nome verdadeiro, como é o caso de E.M.J.

A "máscara do anonimato" [Le masque de l'anonymat, no original] cunhou Marion Brepohl para denominar uma prática de "homens comuns" mas que se achavam encorajados, exatamente pelo anonimato, a denunciar, de maneira perniciosa, os opositores do regime militar, independente de qual papel exerciam nos movimentos de resistência à ditadura (MAGALHÃES, 2009).

Segundo Hannah Arendt, o anonimato é uma "condição essencial no processo de denúncia” (2004, p. 81). Ao fazer uma denúncia, delatando uma pessoa, o homem comum se sente envergonhado, embora, paradoxalmente, se sinta encorajado pela propaganda do regime autoritário, pois o seu ato de delação contribui para manter a ordem social estabelecida e livrar a nação dos inimigos mais nefastos; o comunista, o estrangeiro, o estudante, a mulher. Logo, eles não precisam prestar contas. Como suas denúncias são anônimas não são chamados a nenhuma responsabilidade jurídica, política ou social.

\section{Considerações finais (algumas chaves explicativas)}

A delação e a colaboração com os órgãos de segurança, em si, são "práticas irresponsáveis" (RODRIGUES, 2016), pois são atos que ferem vários valores, como a vida, a honra, a reputação, a imagem, a própria dignidade humana. E suas motivações, se por um lado, revelam algo mais concreto, visível, como a preocupação com a ordem pública e o bem da sociedade, por outro, revelam sentimentos ocultos, como a inveja, o ódio, o ressentimento, a intriga, o desejo de vingança pessoal ou política. Portanto, sem ter a intenção de esgotar o assunto, o que seria impossível no limite de um artigo, expomos algumas chaves explicativas. 
Primeiro é a questão clássica do anticomunismo. Nos bilhetes e nas cartas encaminhados à polícia, algumas frases são emblemáticas. Os autores exigem a “completa erradicação do comunismo", a "repressão aos comunistas", a "apreensão e destruição de livros comunistas" e vinculam os comunistas como sujeitos nocivos, ora tratando-os como "bandidos vermelhos", "perigosos", "degenerados" "bárbaros" etc., ora vinculando-os à figuras depreciativas, tais como "erva daninha" e "monstros". No seu importante trabalho sobre o anticomunismo e o imaginário anticomunista, Rodrigo Patto já alertava para esse processo de evidenciar todos os malefícios que supostamente os comunistas poderiam provocar para a sociedade liberal e cristã.

O comunismo foi identificado à imagem do "mal", tal qual as sociedades humanas normalmente entendem e significam 0 fenômeno, ligando-o à ideia de sofrimento, pecado e morte. A ação dos comunistas traria formas de sofrimento como fome, miséria, tortura e escravização; a nova organização social por eles proposta implicaria em pecado, pois questionava a moral cristã tradicional. (MOTTA, 2002, p. 73)

Não é sem sentido que o demônio seja a mais expressiva imagem utilizada para representar o comunista como um sujeito do mal. "O diabo é vermelho", como bem sentenciou Carla Rodeghero. A literatura especializada sobre o anticomunismo no Brasil tem revelado uma impressionante e infindável lista de vocábulos e expressões depreciativas contra os comunistas (ASSUNÇÃO, 2006; IPÓLITO, 2016; MOTTA, 2002; PRIORI; MATHAIS; FIORUCCI, 2017; RODEGHERO, 2003; SILVA, R., 2017). "Madame Felicidade”, a inquieta delatora que vimos acima, solicitava que a polícia extirpasse a "erva daninha"18 da sociedade (os comunistas) para semear uma boa sementeira, ou seja, uma nova sociedade inaugurada através da força de um golpe militar. Portanto, o anticomunismo nos remete à ideologia do "perigo vermelho" e à disseminação de concepções e de projetos conservadores de cunho autoritário. A ditadura militar, as prisões, os exílios, as torturas e os desaparecimentos de pessoas, no pós-março de 1964, foram resultados, por excelência, dessa cultura política.

\footnotetext{
18 "Erva daninha" cujo "sentido é atribuído dentro do imaginário social para se referir a algo que nasce de forma espontânea e indesejada e interfere sempre de maneira negativa onde floresce, nesse caso: na pátria” (SILVA, R., 2017, p. 89).
} 
Uma outra chave explicativa é a questão do medo. Em uma das cartas que vimos acima, a autora expressava o temor de que as autoridades não cumprissem com o seu destino de limpar a sociedade dos comunistas. Em outra carta, dizendo-se ameaçado de morte, o vigário de Santa Amélia clamava por uma limpeza dos comuno petebistas da cidade. Uma terceira manifestava preocupação com a atuação das forças da repressão, pois segundo o autor, estava havendo um "amolecimento" e, com isso, os comunistas já estavam novamente "levantando a cabeça". Esse temor contra o triunfo dos comunistas é recorrente na maioria das denúncias.

Mas, como enfatiza Jean Delumeau, "nada é mais difícil de analisar do que o medo, e a dificuldade aumenta ainda mais quando se trata de passar do indivíduo ao coletivo" (2009, p. 29). No sentido estrito do termo, o medo individual é uma "emoção-choque" que provoca uma tomada de consciência de um perigo e que pode provocar a ameaça da conservação da vida humana, como por exemplo, o medo de um acidente de avião ou de uma tempestade. E o coletivo? Delumeau, ao pensar a transformação do individual ao coletivo, pergunta: "o que se entende por coletivo?" e agrega dois significados. Primeiro: que coletivo pode designar uma multidão, pensando a multidão das mais diversas formas, sofrendo as ações de pânico e de medo (como por exemplo o medo do desabastecimento provocado pela greve dos caminhoneiros em 2018, para ficar em um caso recente do Brasil). Segundo: que coletivo pode ser um homem qualquer na qualidade de amostra anônima de um grupo. Nos parece que os casos dos delatores que estamos analisando se adequam mais a esta segunda característica, pois como enfatiza, neste caso, Delumeau:

O termo medo ganha um significado menos rigoroso e mais amplo do que nas experiências individuais, e esse singular coletivo recobre uma gama de emoções que vai do temor e da apreensão aos mais vivos terrores. O medo é aqui o hábito que se tem, em um grupo humano, de temer tal ou tal ameaça (real ou imaginária). (DELUMEAU, 2009, p. 32)

Portanto, o medo é um sentimento produzido por uma "causa identificada, que ameaça a segurança, a existência ou a integridade do indivíduo ou da sociedade" (LAURO, 2019, p. 510). Zygmunt Bauman em seu livro Medo Líquido 
(2006) nos fornece algumas reflexões que ajudam na compreensão do fenômeno. Para ele, o medo é o nome que nós damos para a nossa incerteza. E se torna mais assustador quando é difuso, disperso ou assombroso. Bauman diz que os seres humanos conhecem um medo de segundo grau, um medo derivado, que é um sentimento suscetível ao perigo. Um medo social. Isso traz uma sensação de insegurança e vulnerabilidade. E o que traz insegurança para os delatores é o medo do comunismo. "O sentimento anticomunista nasceu espontaneamente, gerado pelo medo e pela insegurança", escreveu Rodrigo Patto (MOTTA, 2002, p. 5).

O comunismo desperta medo. Para os católicos, como a "brasileira e mãe" que marchou nas manifestações da "Família, com Deus pela Liberdade" ou para o anônimo que clamava "por Deus" ao delegado da localidade de Harmonia, o problema do comunismo não era a defesa dos trabalhadores ou dos camponeses, mas sim a concepção de suas doutrinas, que questionava as bases da religião, como por exemplo, a negação de Deus e o apego ao materialismo. Na concepção desses delatores, o medo pela vitória dos "comunistas" era ter suas bases católicas corroídas até a extinção de sua religião. A ideia de que os comunistas colocavam a família brasileira em perigo sensibilizou, sobretudo, as mulheres de classe média. O principal lema das Marchas da Família com Deus pela Liberdade era exatamente a preservação da instituição familiar, o que explica algumas delatoras se qualificarem nas suas denúncias como "mãe e brasileira", "mãe e esposa brasileira". No mesmo sentido, os campos político e empresarial conservador também tinham um discurso intenso de medo do comunismo. Não é à toa que nos primeiros meses de 1964, o medo do comunismo provocou poderosas mobilizações conservadoras com o apoio da chamada grande imprensa. O medo era mais amplo e coletivo.

Mas teria algum fundamento esse medo? Que ameaça representavam os comunistas à ordem social estabelecida ou à instituição familiar, por exemplo? Evidente que essas questões só podem ser respondidas tendo como parâmetro a análise da conjuntura do momento. As cartas e os bilhetes que estamos analisando foram escritos em uma conjuntura política pós-golpe civil-militar. Se fosse no momento anterior, talvez, o medo seria real, pois existia uma 
mobilização comunista bastante intensa. Mas com o limiar da Ditadura, lembremos, a operação limpeza avançou com eficaz destreza na prisão dos comunistas, dos sindicalistas, dos operários e dos camponeses. Logo, a ameaça comunista naquela conjuntura era muito mais imaginada, inventada, do que real.

O medo nos permite enxergar os delatores pela sua dimensão política e social, mas também pelos seus sentimentos, mentalidade e cultura. 0 sentimento do vigário de Santa Amélia é sincero, quando ele enfatiza que limpar a cidade (ou seja, exterminar os comunistas) é uma obra de misericórdia. Ou quando o delator E.J.M. cobrava da polícia o confisco de livros vendidos em uma livraria, por ser literatura "podre, subversiva e caluniosa" e que poderia contaminar o espírito inocente dos curitibanos. Não é só o medo do comunismo. É um conjunto de medos. Medo da falta de segurança, das ideias conflitantes, da ineficiência da polícia em combater o inimigo, real ou imaginário, do outro (estrangeiros, mulheres, prostitutas, estudantes) e medos morais (defesa da moral e dos bons costumes). Essas dimensões do ser humano permitem aos historiadores compreender a sociedade em toda a sua complexidade. A bela definição de Cervantes, em Don Quijote ajuda a elucidar: "O medo tem muitos olhos e enxerga coisas no subterrâneo" (CERVANTES, 1999, p. 104, tradução nossa). Cabe aos historiadores explorar esses subterrâneos e, como alertou Delumeau (2009, p. 14), rever esse silêncio prolongado sobre o medo na história.

O ressentimento é outra chave explicativa. Nós vimos nas denúncias apresentadas no terceiro tópico que a maioria dos delatores tinham proximidade quase íntima com os delatados. Uma delatora que se intitulava "vizinha da comuna"; uma outra que era moradora vizinha do endereço denunciado, a ponto de detalhar a rotina da casa; um outro delator conhecia os livros "podres e subversivos" da livraria; uma outra delatora que denunciou com detalhes a vida do comerciante estrangeiro; um outro relatava as atividades do líder comunista José Rodrigues Vieira Netto, apontando que se ele não fosse neutralizado não haveria o desmantelamento da atuação dos comunistas no Estado; o vigário que relatou informações próximas dos vereadores de Santa Amélia e outros suspeitos do interior do estado. 
Como podemos verificar, o bairro, a rua, a casa, o estabelecimento comercial são espaços cotidianos que de certa forma, foram afetados pela lógica da suspeição em relação ao outro, ao diferente. E com isso, as relações de convivência, de vizinhança, de trabalho e de amizade também são afetadas a partir da ação do Estado.

As delações e a vingança impõem sua lógica nesses contextos de climas conflitivos. O golpe civil-militar e a instauração da ditadura podem ter sido um subterfúgio para se resolver problemas locais, rivalidades pessoais, inimizades, brigas de vizinhos etc. O ódio e o rancor - dos desde abaixo, como dizia Gellately - se materializam nas delações e isso permite a intervenção da polícia política e de outros órgãos de segurança do Estado na ação de investigação e, muitas vezes, na prisão e na condenação dos delatados. As instituições, desde acima portanto, arbitrando esses ressentimentos, muitas vezes manchados de sangue.

Mas o que é o ressentimento? Segundo Maria Rita Kehl, o ressentimento é uma "constelação afetiva que serve aos conflitos característicos do homem contemporâneo, entre as exigências e as configurações imaginárias próprias do individualismo, e os mecanismos de defesa do eu a serviço do narcisismo" (2004, p. 11). Max Scheler (1958), em seu texto centenário, publicado em 1912, já apontava que o ressentimento é uma "constelação afetiva", constituída de uma conjunção maligna formada pelo rancor, pela raiva, pela maldade, por ciúmes, pela inveja, pela malícia e por uma boa dose de desejo de vingança. Ou seja, para o ressentido, o desejo de vingança exerce um papel predominante. Pierre Ansart (2004) também alertava para essas questões. Segundo ele, é preciso considerar os rancores, as invejas, os desejos de vingança, o ódio, as hostilidades ocultas e os fantasmas da morte, pois são exatamente esses os sentimentos e representações designados pelo termo ressentimento.

A vingança é um prato que se come frio, diz um ditado popular. E a delação pode ser a resposta de algo que aconteceu há algum tempo, fantasmas que estavam suspensos, escondidos em algum baú da memória, mas sempre alimentados pela raiva, pela inveja, pelo ódio. Esses sentimentos podem ficar silenciados por tempos, nos subterrâneos da memória, mas não são esquecidos. E no momento oportuno eles emergem à superfície. E os delatores perceberam 
que a conjuntura do golpe, da caça às bruxas, das ações policiais, da chamada operação limpeza promoveram oportunidades para poder delatar à polícia política e aos órgãos de segurança o seu vizinho, o seu parente, o seu colega de trabalho, por alguma injustiça que tenham sofrido ou que pensam ter sofrido, e que até então não tinham tido coragem de agir. É a reação adiada, a vingança adiada, como nos explica a teoria psicanalítica sobre o ressentimento.

\section{Referências}

ALVARENGA, Selma Carmen Alcântara. A atuação da Igreja Católica no processo de organização dos sindicatos de trabalhadores rurais do Norte do Paraná (1962-1969): o caso da Frente Agrária Paranaense. 2008. Dissertação (Mestrado em História) - Universidade Estadual de Maringá, Maringá, 2008.

AMANCIO, Silvia Maria. Ontem, luta pela terra; hoje, monumento histórico: a revolta dos posseiros do Sudoeste do Paraná em suas variadas versões. 2009. Dissertação (Mestrado em História) - Universidade Estadual de Maringá, Maringá, 2009.

ANSART, Pierre. História e memória dos ressentimentos. In: BRESCIANI, Stela; NAXARA, Márcia (org.). Memória e (res)sentimento: indagações sobre uma questão sensível. 2. ed. Campinas: Ed. Unicamp, 2004, p. 15-36.

APOLONIO, Luís. Manual de polícia política e de ordem social. São Paulo: Acadepol, 1954.

ARENDT, Hannah. Responsabilidade e julgamento. São Paulo: Cia das Letras, 2004.

ARENDT, Hannah. Eichmann em Jerusalém: um relato sobre a banalidade do mal. 1. ed. São Paulo: Cia das Letras, 2007.

ARNS, Paulo Evaristo. Brasil: nunca mais: Um relato para a história. 3. ed. Petrópolis: Vozes, 1985.

ASSUNÇÃO, Rosangela Pereira de Abreu. DOPS/MG: Imaginário anticomunista e policiamento político (1935-1964). 2006. 175 f. Dissertação (Mestrado em História) - Universidade Federal de Minas Gerais, Belo Horizonte, 2006. 
BAUMAN, Zygmunt. Medo líquido. Rio de Janeiro: Zahar, 2006.

BOXER, Charles Ralph. Os holandeses no Brasil: 1624-1654. São Paulo:

Companhia Editora Nacional, 1961. (Coleção Brasiliana, n. 312).

BREPOHL, Marion. Censura e repressão (1964-1982): lembrar, mas do quê?

Revista da Anistia e de Justiça de Transição, Brasília, n. 5, p. 138-148, 2012.

BRITO, Angélica. "A cruz vencerá o comunismo": o discurso anticomunista do jornal Folha do Norte do Paraná (1962-1965). 2015. Dissertação (Mestrado em História) - Universidade Estadual de Maringá, Maringá, 2015.

BRUNELO, Leandro. Universos opostos: o embate político entre os militantes do PCB e a DOPS/PR durante o regime militar. Histórica - Revista Eletrônica do Arquivo Público do Estado de São Paulo. São Paulo, n. 34, 2009. Disponível em: http://www.historica.arquivoestado.sp.gov.br/materias/anteriores/edicao34/mat eria04/. Acesso em: 19 maio 2020.

CAMPOS, Marcos Adriani Ferrari. Resistência e repressão no oeste paranaense: o caso da VAR-Palmares em Nova Aurora em 1970. Marechal Cândido Rondon, 2014. Dissertação (Mestrado em História) - Universidade Estadual do Oeste do Paraná, Cascavel, 2014.

CANCELLI, Elizabeth. O mundo da violência: a polícia da era Vargas. 2. ed. Brasília: Ed. UnB, 1994.

CENARRO, Ángela. Matar, vigilar y delatar: la quebra de la sociedade civil durante la guerra y la pós-guerra em España (1936-1948). Historia social, Valência, n. 44, p. 65-86, 2002.

CERVANTES, Miguel de. Don Quijote. Madrid: [S.L.], 1999. E-book. Disponível em: http://www.dominiopublico.gov.br/download/texto/gu000031.pdf. Acesso em: 27 fev. 2021.

CORDEIRO, Janaina Martins. Delações e vida cotidiana no Brasil durante a ditadura civil-militar. Locus - Revista de história, Juiz de Fora, v.25, n. 2, p.223238, 2019.

CURCÓ, Conxita Mir. Repressió militar i societat civil a la Catalunya rural durante I franquisme. L'Avenç, Barcelona, n. 251, p. 1395-1397, oct. 2000 a.

CURCÓ, Conxita Mir. Vivir es sobrevivir: la repressión franquista en la Cataluña rural de pós-guerra. Lleida: Milenio, 2000b. 
DOPS. Pastas Temáticas números 212.94, 264.29, 797.94, 798.94, 799.94, 1084.131, 1143a.137, 1782.213 e 1870.213.

DEAP. Departamento Estadual de Arquivo Público do Estado do Paraná. Fundo DOPS. Fichas nominais números 02.809, 41.463, 45.992, 45.994 e 46.563.

DEAP. Departamento Estadual de Arquivo Público do Estado do Paraná. Fundo DOPS. Pastas individuais números 2193.400 e 2194.400.

-DELUMEAU, Jean. História do medo no ocidente (1300-1800). São Paulo: Companhia do Bolso, 2009.

FABRE, Jaume. La delació dins la repressió franquista de postguerra. L'Avenç, Barcelona, n. 75, p. 30-39, oct. 1984.

FICO, Carlos. "Prezada censura...": cartas ao regime militar. Topoi. Rio de Janeiro, v. 3, n. 5, p. 251-286, 2002.

FICO, Carlos. Além do golpe: versões e controvérsias sobre 1964 e a ditadura militar. 2. Ed. Rio de Janeiro: Record, 2012.

FITZPATRICK, Sheila; GELLATELY, Robert (orgs). Accusatory practices: denunciation in modern european history (1789-1989). Chicago: The University of Chicago Press Book, 1996a.

FITZPATRICK, Sheila; GELLATELY, Robert. Introduction to the practices of denunciation in modern european history. The Journal of Modern History, Chicago, v. 68, n. 4, p. 747-767, 1996b.

FLORINDO, Marcos Tarcísio. O serviço reservado da delegacia de ordem política e social de São Paulo na era Vargas. São Paulo: Editora UNESP, 2006.

FOUCAULT, Michel. Vigiar e punir. 10. ed. Petrópolis: Vozes, 1993.

GABEIRA, Fernando. O que é isso companheiro? São Paulo: Cia das Letras, 2009.

GELLATELY, Robert. Apoiando Hitler: consentimento e coerção na Alemanha Nazista. Rio de Janeiro: Record, 2011.

HELLER, Milton Ivan. Depoimento 1: visão crítica sobre o Partido. In: CODATO, Adriano; KIELLER, Marcio. Velhos vermelhos: história e memória dos dirigentes comunistas no Paraná. Curitiba: Ed.UFPR, 2008, p. 87-102.

HERLER, Thomaz Joezer. Formação e trajetória do primeiro MR-8:

possibilidades e limites de construção de uma vanguarda revolucionária 
político-militar (1964-1969). Marechal Cândido Rondon, 2015. Dissertação (Mestrado em História) - Universidade Estadual do Oeste do Paraná, Cascavel, 2015.

IPÓLITO, Verônica Karina. O vermelho que violenta a ordem: os comunistas sob o olhar do DOPS no Paraná. 2016. 253 f. Tese (Doutorado em História) Faculdade de Ciências e Letras / Universidade Estadual Paulista - Unesp, Assis, 2016.

JOLY, Laurent (org.). Introduction. In: La délation dans la France des années noires. Paris: Perrin, 2012.

KEHL, Maria Rita. Ressentimento. São Paulo: Casa do Psicólogo, 2004.

KOLING, Paulo José. A revolta de 1957 no Sudoeste do Paraná: a luta pela terra entre memórias e comemorações. Guarapuava: Ed. Unicentro, 2018.

LAURO, Claudia Rosa. Miedo. In: COLLING, Ana Maria; TEDESCHI, Losandro Antônio (org.). Dicionário crítico de gênero. 2. ed. Dourados: Ed. UFGD, 2019.

LVOVICH, Daniel. Sospechar, delatar, incriminar: las denuncias contra el enemigo político en la última ditadura militar Argentina. Ayer, Buenos aires, v. 107, n. 3, p. 73-98, 2017.

MACHADO, Paulo Pinheiro. Lideranças do Contestado. Campinas: Ed. Unicamp, 2004.

MAGALHÃES, Marion Brepohl. A lógica da suspeição: sobre os aparelhos repressivos à época da ditadura militar no Brasil. Revista Brasileira de História, São Paulo, v. 17, n. 23, p. 203-220, 1997.

MAGALHÃES, Marion Brepohl. Marion. Les pouvoirs insidieux des hommes ordinaires pendant la Dictature militaire au Brésil. Droit et cultures: Revue Internationale Interdisciplinaire, Paris, v. 57, n. 1, p. 217-224, 2009. Disponível em: http://journals.openedition.org/droitcultures/1366. Acesso em: 06 jan. 2019.

MANSAN, Jaime Valim. Subversivos: ditadura e controle social na educação superior do Brasil (1964-1988). 2014. 396 f. Tese (Doutorado em História) Pontifícia Universidade Católica do Rio Grande do Sul, Porto Alegre, 2014.

MEIRELES, Cecília. Romanceiro da inconfidência. 3. ed. Rio de Janeiro: Nova Fronteira, 1989.

MONTEIRO, Cláudia. "Fora dos trilhos": a experiência da militância comunista na rede de Viação Paraná-Santa Catarina (1934-1945. 2007. 135 f. Dissertação 
(Mestrado em História) - IFCH/Universidade Federal do Rio Grande do Sul, Porto Alegre, 2007.

MOTTA, Rodrigo Patto Sá. Em guarda contra o perigo vermelho: o anticomunismo no Brasil (1917-1964). São Paulo: Perspectiva, 2002.

O QUE é isso companheiro? Direção: Bruno Barreto. Rio de Janeiro: L. C. Barreto Ltda, 1997. 1 DVD (106 min.).

PEREIRA, Márcio José. Sentimentos, ressentimentos e violência: a ação da Polícia Política no Paraná em relação aos indivíduos de origem germânica (19421945). 2017. 283 f. Tese (Doutorado em História) - Universidade Federal do Paraná, Curitiba, 2017.

PRADELA, Luana Milani. Os grupos dos onze no Paraná: Trajetórias. 2019. 179 f. Dissertação (Mestrado em História) - Unioeste, Campus de Marechal Cândido Rondon, Marechal Cândido Rondon, 2019.

PRIORI, Angelo. O levante dos posseiros: a revolta camponesa de Porecatu e a ação do PCB no campo. Maringá: Eduem, 2012.

PRIORI, Angelo. O protesto do trabalho: história das lutas sociais dos trabalhadores rurais do Paraná (1954-1964). Maringá: Eduem, 1996.

PRIORI, Angelo. Polícia política e ordenamento jurídico (Paraná: 1930-1964). In: MUNIZ, Altemar da Costa; MARTINS, Luis Carlos dos Passos. História política: interfaces e diálogos. Fortaleza: Ed. UECE ; Porto Alegre: EdiPucRS, 2016, p. 205230.

PRIORI, Angelo; MATHIAS, Meire; FIORUCCI, Rodolfo (org.). O anticomunismo e a cultura autoritária no Brasil. Curitiba: Prismas, 2017.

QUINALHA, Renan Honório. Contra a moral e bons costumes: a política sexual da ditadura brasileira (1964-1985). 2017. 329 f. Tese (Relações Internacionais) Instituto de Relações Internacionais, Universidade de São Paulo, São Paulo, 2017.

REGGIANI, João Paulo de Medeiros. Repressão aos “Grupo dos Onze” na região Norte do Estado do Paraná (1963-1964). 2015. 138 f. Dissertação (Mestrado em História) - Universidade Estadual de Maringá, Maringá, 2015.

REIS FILHO, Daniel Aarão et. al. Versões e ficções: o sequestro da história. São Paulo: FPA, 1997.

RODEGHERO, Carla Simone. O diabo é vermelho: imaginário anticomunista e Igreja Católica no Rio Grande do Sul. 2. ed. Passo Fundo: Editora da UPF, 2003. 
RODRIGUES, João Gaspar. A prática da delação e sua funcionalidade em ambiente democrático. De Jure, Belo Horizonte, n. 26, p. 77-107, 2016.

ROLIM, Rivail Carvalho. A reorganização da polícia no Estado do Paraná nos anos 1950. Revista de História Regional, Ponta Grossa, v. 5, n. 1, p. 153-166, 2000.

SAMWAYS, Daniel Trevisan. Imaginários sociais, sentimentos reais: medo e paranoia no discurso anticomunista do Serviço Nacional de Informações (19701973). 2014. 250 f. Tese (Doutorado em História) - Universidade Federal do Paraná, Curitiba, 2014.

SCHELER, Max. L’homme du ressentiment. Paris: Gallimard, 1958.

SILVA, Carla Luciana; BATISTA, Alfredo (org.). Combatentes: tempo de falar: depoimentos da audiência pública da comissão estadual da verdade do Paraná. Cascavel: Edunioeste, 2016.

SILVA, Marcília Gama. Informação, repressão e memória: a construção do estado de exceção no Brasil na perspectiva do DOPS/PE (1964-1985). 2007. Tese (Doutorado em História) - Universidade Federal de Pernambuco, Recife, 2007.

SILVA, Rodrigo Pereira. Os informantes da polícia política e a questão do anticomunismo durante a ditadura civil-militar (Paraná, 1964-1985). 2017. 116 f. Dissertação (Mestrado em História) - Universidade Estadual de Maringá, Maringá, 2017.

SOUSA, Reginaldo Cerqueira. República das mulheres de virtude: um estudo sobre as bases sociais de apoio ao governo dos militares (1964-1985). 2016. 219 f. Tese (Doutorado em História) - Universidade Federal do Paraná, Curitiba, 2016.

SOUZA, Sérgio Alves. Duas vezes Calabar: 1632/1973. Projeto História. São Paulo, v. 29, n. 2, p. 499-512, 2004. 